\title{
Study of the Interference between Plectranthus Species Essential Oils from Brazil and Aminoglycosides
}

\author{
Fabíola Fernandes Galvão Rodrigues, ${ }^{1}$ José Galberto Martins Costa, ${ }^{1,2}$ \\ Fábio Fernandes Galvao Rodrigues, ${ }^{2}$ and Adriana Rolim Campos ${ }^{2,3}$ \\ ${ }^{1}$ Programa de Pós-Graduação em Biotecnologia, Rede Nordeste de Biotecnologia, Universidade Estadual do Ceará, \\ Avenida Paranjana 1700, Campus do Itaperi, 60740-000 Fortaleza, CE, Brazil \\ ${ }^{2}$ Programa de Pós-Graduação em Bioprospecção Molecular, Departamento de Química Biológica, Laboratório de Pesquisa de Produtos \\ Naturais, Universidade Regional do Cariri, Rua Cel. Antônio Luiz 1161, Pimenta, 63105-000 Crato, CE, Brazil \\ ${ }^{3}$ Programa de Pós-Graduação em Biotecnologia, Rede Nordeste de Biotecnologia, Universidade de Fortaleza, \\ Avenida Washington Soares 1321, Edson Queiroz, 60811-905 Fortaleza, CE, Brazil \\ Correspondence should be addressed to Fabíola Fernandes Galvão Rodrigues; fabiolafer@gmail.com
}

Received 10 August 2012; Accepted 7 March 2013

Academic Editor: Andrea Pieroni

Copyright (C) 2013 Fabíola Fernandes Galvão Rodrigues et al. This is an open access article distributed under the Creative Commons Attribution License, which permits unrestricted use, distribution, and reproduction in any medium, provided the original work is properly cited.

\begin{abstract}
Plectranthus is one of the most representative genera of Lamiaceae family. In this study, the essential oils from Plectranthus amboinicus, Plectranthus ornatus, and Plectranthus barbatus were investigated for their chemical composition and antimicrobial and modulatory activities. The major components found were carvacrol (54.4\% - P. amboinicus) and eugenol (22.9\% - P. ornatus e $25.1 \%$ - P. barbatus). In vitro antimicrobial activity was conducted against Escherichia coli, Proteus vulgaris, Bacillus cereus, Pseudomonas aeruginosa, Staphylococcus aureus, and Staphylococcus aureus (multiresistant) using microdilution method. The results of bioassay showed that all strains were sensitive to the oils, except $P$. aeruginosa that was resistant to $P$. amboinicus and $P$. ornatus. A synergistic effect of all essential oils combined with the aminoglycosides was demonstrated. These results show that P. amboinicus, P. ornatus, and P. barbatus inhibit the growth of pathogenic microorganism, and besides this they present antibiotic modifying activity, providing a new perspective against the problem of bacterial resistance to antibiotics.
\end{abstract}

\section{Introduction}

The increasing antibiotic resistance has improved the interest in the development of new antimicrobial compounds from medicinal plants. The need for new classes of safe and natural antimicrobials able to control the microorganism growth and infections has become more urgent [1]. Synthetic drugs have been associated with several side effects on human health. Furthermore, microorganisms indicated a resistance to synthetic antimicrobial agents, which is a serious and immediate concern. Taken together, these facts point to the need for new alternative drugs from natural source.

However, the identification and evaluation of these products, presenting optimized levels of antimicrobial activity, can be considered as an important world challenge for food and drugs industries.
Essential oils or some of their components are used in perfumes and makeup products, in sanitary products, in dentistry, in agriculture, as food preservers and additives, and as natural remedies [2]. This range of uses is attributed to the essential oils chemical composition, mainly terpenes and terpenoids. Uncountable studies point to the antimicrobial effect of essential oils and isolate constituents, and besides this interactions between the different natural chemical components and synthetic antibiotics can occur, leading to a potentialization of the modulatory effect $[3,4]$.

Analysis of the antimicrobial activity of chemical constituents of the oils, alone or in combination, in different treatments using different microorganisms can produce lethal effects at lower doses, avoiding changes and providing various perspectives on the problem of bacterial resistance to antibiotics $[1,5]$. 
Some synthetic chemical compounds or from natural sources are able to increase the activity of specific antibiotics and to revert the natural resistance of particular bacteria against some antibiotics [6,7]. The ability of natural or nonconventional synthetic antibiotics to reinforce the antibiotic activity or to modify the resistance allows the classification of these compound as modifiers of antibiotic activity [8].

Genus Plectranthus (Lamiaceae) comprises about 300 species of herbs and shrubs native to tropical regions. The most frequently cited use of species of Plectranthus is for their medicinal properties, which accounts for over $85 \%$ of all uses $[9,10]$. The species are used for the treatment digestive disturbances (21 species), skin affections (20 species), respiratory infections (15 species), general infections and fever (20 species), genitourinary infections (08 species), pain (09 species), musculoskeletal conditions (09 species). Plectranthus species are used also to treat blood and circulation conditions and the nervous system disturbances [10].

It is known that Plectranthus species present a great biosynthetic capacity to produce diverse chemical classes from secondary cell metabolism, mainly diterpenoids and triterpenoids, some of them showing confirmed biological properties [11].

Plectranthus amboinicus, popularly known as "malvarisco," "hortelã grande" and "hortelã-da-folha-grossa," is a long lengh, perennial, aromatic herb. This specie is one of the most popular medicinal plants used in the northeast region of Brazil because its antimicrobial, balsamic, and anti-inflammatory properties $[12,13]$. Previous studies have demonstrated that the leaves of this specie possess bronchodilator, antituberculous, antibacterial, antifungal, and antiviral activities [13-16].

Plectranthus barbatus, known in popular medicine as "malva-santa" or "malva-sete-dores," is a herbaceous subshrub presenting aromatic, bitter and flexible leaves. The interest in studying this specie was stimulated by the wide use of its leaves to treat digestive disturbances in substitution for "boldo do Chile" (Peumus boldus). P. barbatus is also emplyoed in the treatment of nauseas, gastritis, and intestinal spasms [10]. Pharmacological studies have reported the gastric hyposecretive activity of $P$. barbatus. This activity is probably related to the presence of the diterpene barbatusin that possesses antidyspeptic and antiulcerous properties [10].

Plectranthus ornatus ("boldo gambá" and "boldo miúdo") is largely employed in popular medicine to treat hepatic and digestive affections. This pharmacological importance is attributed to the diterpenes found in its leaves [17]. Besides barbatusin previously found in $P$. barbatus, a new diterpene in $P$. ornatus leaves was reported by Albuquerque et al. [18, 19]. The authors propose the substitution of $P$. ornatus by $P$. barbatus, even without the confirmation of the gastric hyposecretive activity. Rijo et al. [20] showed the isolation of 3 diterpenes, similarly to forskolin, in the leaves of $P$. ornatus and two of them possess antibacterial activity.

Here we describe the first report of the antibiotic modifier activity of Plectranthus essential oils.

\section{Materials and Methods}

2.1. Plant Material. The aerial parts of $P$. amboinicus, $P$. barbatus, and P. ornatus were collected in March 2010, from the Medicinal Plants Garden at the Regional University of Cariri (URCA). Voucher specimens were deposited in the Herbarium Caririense D $\alpha$ rdano de Andrade Lima (numbers 3037, 3038, and 3039, resp.).

2.2. Essential Oil Extraction. Samples of $P$. amboinicus, $P$. barbatus, or $P$. ornatus fresh leaves $(500 \mathrm{~g})$ were triturated and submitted to hydrodistillation process, in a Clevengertype apparatus for 2 hours. The collected essential oils were subsequently dried by anhydrous sodium sulfate $\left(\mathrm{Na}_{2} \mathrm{SO}_{4}\right)$ and stored under refrigeration at $<4^{\circ} \mathrm{C}$ until analyzed and tested.

2.3. GC/MS Analysis. Analysis of the volatile constituents of essential oil was carried out on a Hewlett-Packard Model 5971 GC/MS using a nonpolar DB-5 fused silica capillary column ( $30 \mathrm{~m} \times 0.25 \mathrm{~mm}$ i.d., $0.25 \mu \mathrm{m}$ film thickness) carrier gas helium, flow rate $1 \mathrm{~mL} / \mathrm{min}$, and with split mode. The injector temperature and detector temperature were $250^{\circ} \mathrm{C}$ and $200^{\circ} \mathrm{C}$, respectively. The column temperature was programmed from $35^{\circ} \mathrm{C}$ to $180^{\circ} \mathrm{C}$ at $4^{\circ} \mathrm{C} / \mathrm{min}$, and then $180^{\circ} \mathrm{C}$ to $250^{\circ} \mathrm{C}$ at $10^{\circ} \mathrm{C} / \mathrm{min}$, split ratio $(1: 30)$; mass spectra were recorded from 30 to $450 \mathrm{~m} / \mathrm{z}$, electronic impact $70 \mathrm{eV}$. Individual components were identified by computer library MS searches using retention indices as a preselection routine and visual inspection of the mass spectra from the literature for confirmation.

\subsection{Antibacterial Activity and Minimal Inhibitory Concen-} tration (MIC). The antibacterial activities of the essential oils were investigated by employing a microdilution method, recommended by M7-A6 [21]. The assay was carried out with five bacterial species obtained from Fundação Oswaldo Cruz (FIOCRUZ): Escherichia coli ATCC 25922, Proteus vulgaris ATCC 13135, Bacillus cereus ATCC 33018, Pseudomonas aeruginosa ATCC 15442, Staphylococcus aureus ATCC 12692, and a multiresistant strain Staphylococcus aureus SA 358. The initial solution of essential oils was diluted to reach a final concentration in the range of 512 to $8 \mu \mathrm{g} / \mathrm{mL}$. All experiments were performed in triplicate and the microdilution trays were incubated at $35 \pm 2^{\circ} \mathrm{C}$ for $24 \mathrm{~h}$. Antibacterial activity was detected using a colorimetric method by adding $25 \mu \mathrm{L}$ of resazurin staining $(0.01 \%)$ aqueous solution in each well at the end of the incubation period. The minimal inhibitory concentration (MIC) was defined as the lowest EOLm concentration able to inhibit the bacteria growth, as indicated by resazurin staining (bacteria died cells are not able to change the staining color by visual observation, blue to red).

2.5. Modulatory Activity by Direct Contact. To evaluate the essential oils as modulators of antibiotic resistance, the MICs of aminoglycosides (kanamycin, amikacin, and gentamicin) against the analyzed strains were determined in the presence or absence of the essential oils using the microdilution test. 
TABle 1: Chemical composition (\%) of the leaf oils of P. amboinicus, P. ornatus, and P. barbatus.

\begin{tabular}{|c|c|c|c|c|c|}
\hline \multirow{2}{*}{ Components } & \multirow{2}{*}{$\mathrm{IR}^{\mathrm{a}}$} & \multirow{2}{*}{$\mathrm{IR}^{\mathrm{b}}$} & \multicolumn{3}{|c|}{ Composition (\%) } \\
\hline & & & P. amboinicus & P. ornatus & P. barbatus \\
\hline$\alpha$-pinene & 941 & 939 & 0.8 & 0.7 & 0.3 \\
\hline sabinene & 972 & 975 & - & 1.2 & 0.6 \\
\hline$\beta$-pinene & 981 & 979 & 1.2 & 2.2 & - \\
\hline$\beta$-myrcene & 987 & 991 & - & - & 1.8 \\
\hline p-cymene & 1022 & 1025 & 10.3 & - & - \\
\hline cis- $\beta$-ocimene & 1032 & 1037 & 1.3 & 2.2 & 1.9 \\
\hline trans- $\beta$-ocimene & 1046 & 1050 & - & 0.9 & 1.2 \\
\hline$\gamma$-terpinene & 1064 & 1060 & 5.9 & - & - \\
\hline Terpinen-4-ol & 1173 & 1177 & 0.9 & 2.5 & - \\
\hline Thymol methyl ether & 1235 & 1235 & 1.6 & - & - \\
\hline Thymol & 1288 & 1290 & 1.3 & 16.6 & 15.3 \\
\hline Carvacrol & 1296 & 1299 & 67.9 & 13.9 & 12.1 \\
\hline Eugenol & 1365 & 1359 & - & 22.9 & 25.1 \\
\hline$\alpha$-copaene & 1375 & 1377 & - & 2.4 & 8.9 \\
\hline$\beta$-cubebene & 1385 & 1388 & - & 1.2 & 3.7 \\
\hline$\beta$-caryophyllene & 1422 & 1419 & 2.8 & 18.2 & 10.7 \\
\hline (E)- $\alpha$-bergamotene & 1430 & 1435 & 1.4 & - & 0.5 \\
\hline$\alpha$-humulene & 1451 & 1455 & 0.7 & 0.8 & 1.6 \\
\hline Aromadendrene & 1458 & 1460 & 1.2 & - & - \\
\hline$\beta$-bisabolene & 1509 & 1506 & - & - & - \\
\hline$\delta$-cadinene & 1519 & 1523 & - & - & 1.4 \\
\hline trans-nerolidol & 1558 & 1563 & - & 0.8 & 0.2 \\
\hline Caryophyllene oxide & 1582 & 1583 & - & 0.3 & 2.4 \\
\hline epi- $\alpha$-cadinol & 1638 & 1640 & - & - & 0.6 \\
\hline Total identified & & & 97.3 & 86.4 & 88.3 \\
\hline
\end{tabular}

${ }^{a}$ Relative retention indices experimental: $n$-alkanes were used as reference points in the calculation of relative retention indices. ${ }^{b}$ Relative retention indices (the literature values).

TABle 2: Minimal inhibitory concentration (MIC) of P. amboinicus, $P$. ornatus, and P. barbatus fresh leaves essential oils.

\begin{tabular}{lccc}
\hline \multirow{2}{*}{ Microorganism } & \multicolumn{3}{c}{ MIC $(\mu \mathrm{g} / \mathrm{mL})$} \\
\hline E. coli ATCC 25922 & 256 & 512 & 512 \\
P. vulgaris ATCC 13315 & 64 & 128 & 256 \\
B. cereus ATCC 33018 & 512 & 512 & 64 \\
P. aeruginosa ATCC 15442 & $\geq 1024$ & $\geq 1024$ & 512 \\
S. aureus ATCC 12692 & 128 & 128 & 32 \\
S. aureus SA 358 & 32 & 256 & 512 \\
\hline
\end{tabular}

Subinhibitory concentrations (MIC 1/8) in 10\% BHI were used.

The antibiotics solutions $(1000 \mu \mathrm{g} / \mathrm{mL})$ were prepared in distillated water for use the same day. A total of $100 \mu \mathrm{L}$ of the antibiotic solution, using use serial dilutions $(1: 2)$, was added to the wells containing $10 \% \mathrm{BHI}$ and the diluted bacterial suspension $(1: 10)$. Microplates were incubated for $24 \mathrm{~h}$ at room temperature and the antibacterial activity was determined as described before.

\section{Results and Discussion}

3.1. Essential Oils Yields and Composition. The essential oils obtained by hydrodistillation presented different yields: $0.3 \%$ P. amboinicus, $0.1 \%$ P. barbatus, and $0.2 \%$ P. ornatus, $\mathrm{v} / \mathrm{v}$. According to Table 1, the main constituents found were carvacrol (54.4\% - P. amboinicus) and eugenol (22.9\%-P. ornatus and $25.1 \%-P$. barbatus). Although these species belong to the same genus, they exhibit distinct chemical and pharmacological properties [18]. $\alpha$-humulene, $\beta$-caryophyllene, carvacrol, thymol, cis- $\beta$-ocimene, and $\alpha$-pinene were also found as uncommon constituents.

As reported by de Albuquerque et al. [18, 19], the essential oil from $P$. ornatus presented trans- $\beta$-caryophyllene $(9.6 \%-$ $62.4 \%)$, eugenol $(38.0 \%)$, and timol $(14.1 \%)$ as the major components.

Previous works show that the essential oils from aerial parts and roots from $P$. barbatus possess $\alpha$-pinene, $\beta$-phellandrene, (Z)- $\beta$-ocimene, manol, and abietadiene as main constituents $[18,22]$.

Costa [23] identified 23 components (94.13\%) in the essential oil from $P$. barbatus leaves, with predominance of sesquiterpenes (10) and monoterpenes (09). Two oxygenated 
sesquiterpenes and two diterpenes were found too. The essential oil from fresh leaves of $P$. amboinicus collected in the South of Ceará is composed of timol (64.3\%), $p$-cymene (10.3\%), $\gamma$-terpinene (9.9\%) and $\beta$-caryophyllene (2.8\%) [14].

Twenty-six compounds were found in an Indian sample of $P$. amboinicus essential oil. The major chemical compounds were carvacrol $(28.65 \%)$ followed by thymol $(21.66 \%), \alpha$ humulene $(9.67 \%)$, undecanal $(8.29 \%), \gamma$-terpinene $(7.76 \%)$, $\rho$-cymene $(6.46 \%)$, caryophyllene oxide $(5.85 \%), \alpha$-terpineol (3.28\%), and $\beta$-selinene (2.01\%) [24].

3.2. Antimicrobial Activity. The antibacterial activities of Plectranthus essential oils were assayed in vitro by a microdilution method against six pathogenic bacteria. Table 2 summarizes the microbial growth inhibition by each essential oil. According to the results, the essential oils were found to be active against Gram-positive and Gram-negative strains.

P. amboinicus essential oil was found to be active against all pathogenic bacteria except Pseudomonas aeruginosa. The strongest antibacterial activity was seen against Staphylococcus aureus SA 358 with a MIC value of $32 \mu \mathrm{g} / \mathrm{mL}$ followed by Proteus vulgaris ATCC 13315 MIC $64 \mu \mathrm{g} / \mathrm{mL}$. Costa et al. [14] reported that the essential oil from P. amboinicus, using the disc diffusion assay, inhibited the growth of Staphylococcus aureus ATCC 10390, Proteus vulgaris ATCC 13315, and Aeromonas caviae ATCC 15468. The essential oil was not active against Escherichia coli ATCC 25922, and Enterobacter cloacal ATCC 23355. The extract of $P$. amboinicus was active against seven Staphylococcus strains (halo inhibition of $13 \mathrm{~mm}$ ), but it was not active against $P$. aeruginosa and Candida ssp. [25]. Costa et al. [14] evaluated the essential oil from $Z$. articulatum against a multiresistant S. aureus (SA 358) and a MIC value of $\mu \mathrm{g} / \mathrm{mL}$ was found; this value $(<1000 \mu \mathrm{g} / \mathrm{mL})$ was clinically significant. So, the results obtained here are considered relevant, once a lower MIC value was found against the same multiresistant strain [26].

$P$. barbatus was active against all tested strains, mainly against the Gram-positive Bacillus cereus ATCC 33018 and Staphylococcus aureus ATCC 12692 with MIC values of 64 and $32 \mu \mathrm{g} / \mathrm{mL}$, respectively.

Previous studies showed that roots, barks, and leaves of Plectranthus barbatus, collected in the south region of Africa, exhibited antibacterial activity. This confirms that Lamiaceae species are recognized by the presence of terpenoids with antifungal, antibacterial, and insecticidal actions [27]. Matu and Staden [27] verified that hexane and methanolic extracts of roots, barks, and leaves from P. barbatus were active against Bacillus subtilis, Micrococcus luteus, and Staphylococcus aureus.

$P$. ornatus was also active against all strains tested, except $P$. aeruginosa. The lower MIC values found was $128 \mu \mathrm{g} / \mathrm{mL}$, for Proteus vulgaris and Staphylococcus aureus ATCC 12692.

Essential oils, rich in phenolic compounds, possess high levels of antimicrobial activity [28-30], like the results obtained here.

The phenolic compound, thymol and carvacrol, have been described as the major components of essential oils from
Plectranthus species, being responsible for the antimicrobial properties of the oils [31]. Carvacrol and thymol present capability of dissolving into the cytoplasm membrane aligning among the fatty acid chains providing an increase in the cytoplasm membrane passive permeability $[32,33]$.

Ait-Ouazzou et al. [3] showed that $P$. aeruginosa was the bacterial strain most resistant to several essential oil constituents, being only moderately inhibited by carvacrol. Therefore, oxygenated monoterpenes showed higher inhibitory activity on microbial growth than did hydrocarbons. Phenolic compounds, as carvacrol and timol, are more efficient than hydrocarbons, alcohols, and esters.

The bacteriostatic properties of essential oils rich in thymol were previously reported $[34,35]$. Thymol presented a better activity against $P$. aeruginosa, $S$. aureus and $E$. coli than did an essential oil rich in thymol [36].

Several studies have demonstrated that essential oils and extracts from other Plectranthus species are between the most potent antimicrobial natural products $[27,37,38]$. In this study, it was shown that all essential oils tested were more effective against Gram-positive strains, in comparison to Gram-negative. These results are in agreement with the report of Othman (2005) [39]; in this study Gram-negative microorganisms are more resistant to antimicrobials agents. This resistance may be is related to the presence of a peptidoglycan barrier in Gram-negative strains, thus restricting of antibiotic access to the target.

3.3. Modulatory Activity of Direct Contact Assay. Table 3 shows that antibiotic activity of amikacin, kanamycin and gentamicin was better in the presence of the essential oils. $P$. amboinicus potentialized the antibiotic activity of all drugs against all strains tested. P. ornatus did not interfere with the amikacin effect against $E$. coli (ATCC 25922). The same response was observed with gentamicin against $B$. cereus (ATCC 33018). A synergistic effect between P. barbatus and aminoglycosides was observed.

Essential oils may interact with and affect the plasma membrane, interfering with respiratory chain activity and energy production $[8,40]$. The mechanisms by which essential oils can inhibit microorganisms involve different modes of action and in part may be due to their hydrophobicity [41]. Some research works show that essential oils (Lantana camara, Melaleuca leucadendron, and Ocimum gratissimum) demonstrated synergism with antibiotics by direct contact [42].

Components of essential oils as thymol and carvacrol may act as membrane permeabilizers, enhancing the intake of antibiotics [43]. Impairment of bacterial enzyme systems may also be a potential mechanism of action [44].

In this way, this report represents the first report regarding the modulatory activity of essential oils from Plectranthus species. Others works indicated different antibiotics combinations tested in vitro and clinically applied; however, combinations between natural products and synthetic drugs have been less published [45]. The results obtained here suggest that the essential oils from Plectranthus species can 
TABLE 3: MIC values of aminoglycosides in the presence and absence of essential oils.

\begin{tabular}{|c|c|c|c|c|c|}
\hline & \multicolumn{2}{|c|}{ Strains } & \multirow{2}{*}{$\frac{\text { Amikacin }(\mu \mathrm{g} / \mathrm{mL})}{64}$} & \multirow{2}{*}{$\frac{\text { Kanamycin }(\mu \mathrm{g} / \mathrm{mL})}{64}$} & \multirow{2}{*}{$\begin{array}{c}\text { Gentamicin }(\mu \mathrm{g} / \mathrm{mL}) \\
128\end{array}$} \\
\hline \multirow{10}{*}{ P. amboinicus } & \multirow{2}{*}{ S. a. 12692} & MIC & & & \\
\hline & & $\mathrm{EO}(16 \mu \mathrm{g} / \mathrm{mL})$ & 32 & 16 & 64 \\
\hline & \multirow{2}{*}{ S. a. 12624} & MIC & 128 & 64 & 64 \\
\hline & & $\mathrm{EO}(4 \mu \mathrm{g} / \mathrm{mL})$ & 64 & 8 & 16 \\
\hline & \multirow{2}{*}{ B. c. 33018} & MIC & 128 & 64 & 64 \\
\hline & & $\mathrm{EO}(64 \mu \mathrm{g} / \mathrm{mL})$ & 16 & 32 & 16 \\
\hline & \multirow{2}{*}{ P.v. 13315} & MIC & 64 & 32 & 128 \\
\hline & & $\mathrm{EO}(8 \mu \mathrm{g} / \mathrm{mL})$ & 16 & 8 & 16 \\
\hline & \multirow{2}{*}{ E.c. 25922} & MIC & 64 & 128 & 64 \\
\hline & & $\mathrm{EO}(32 \mu \mathrm{g} / \mathrm{mL})$ & 32 & 64 & 32 \\
\hline \multirow{10}{*}{ P. ornatus } & \multirow{2}{*}{ S. a. 12692} & MIC & 64 & 64 & 128 \\
\hline & & $\mathrm{EO}(64 \mu \mathrm{g} / \mathrm{mL})$ & 16 & 8 & 8 \\
\hline & \multirow{2}{*}{ S. a. 12624} & MIC & 128 & 64 & 64 \\
\hline & & $\mathrm{EO}(64 \mu \mathrm{g} / \mathrm{mL})$ & 64 & 32 & 32 \\
\hline & \multirow{2}{*}{ B. c. 33018} & MIC & 128 & 64 & 64 \\
\hline & & $\mathrm{EO}(16 \mu \mathrm{g} / \mathrm{mL})$ & 16 & 32 & 64 \\
\hline & \multirow{2}{*}{ P.v. 13315} & MIC & 64 & 32 & 128 \\
\hline & & $\mathrm{EO}(16 \mu \mathrm{g} / \mathrm{mL})$ & 32 & 16 & 32 \\
\hline & \multirow{2}{*}{ E.c. 25922} & MIC & 64 & 128 & 64 \\
\hline & & $\mathrm{EO}(32 \mu \mathrm{g} / \mathrm{mL})$ & 64 & 16 & 8 \\
\hline \multirow{10}{*}{ P. barbatus } & \multirow{2}{*}{ S. a. 12692} & MIC & 64 & 64 & 128 \\
\hline & & $\mathrm{EO}(64 \mu \mathrm{g} / \mathrm{mL})$ & 16 & 8 & 8 \\
\hline & \multirow{2}{*}{ S. a. 12624} & MIC & 128 & 64 & 128 \\
\hline & & $\mathrm{EO}(64 \mu \mathrm{g} / \mathrm{mL})$ & 16 & 32 & 32 \\
\hline & \multirow{2}{*}{ B. c. 33018} & MIC & 128 & 64 & 64 \\
\hline & & $\mathrm{EO}(16 \mu \mathrm{g} / \mathrm{mL})$ & 64 & 32 & 16 \\
\hline & \multirow{2}{*}{ P.v. 13315} & MIC & 64 & 32 & 128 \\
\hline & & $\mathrm{EO}(16 \mu \mathrm{g} / \mathrm{mL})$ & 32 & 16 & 32 \\
\hline & \multirow{2}{*}{ E. c. 25922} & MIC & 64 & 128 & 64 \\
\hline & & $\mathrm{EO}(32 \mu \mathrm{g} / \mathrm{mL})$ & 8 & 32 & 16 \\
\hline
\end{tabular}

E. c. (Escherichia coli), P. v. (Proteus vulgaris), B.c. (Bacillus cereus), P. a. (Pseudomonas aeruginosa).

suppress the growth of Gram-positive and Gram-negative bacteria and they could be a source of metabolites with antibacterial modifying activity to be used as adjuvants to antibiotic therapy against these pathogens. So research should be stimulated to identify more natural compounds with synergistic behavior.

\section{Conclusion}

The results of this study suggest that the chemical components of essential oils of the Plectranthus genus can suppress the growth of Gram-positive and Gram-negative pathogenic bacteria. Especially for large amount of phenolic compounds such as thymol, carvacrol, and eugenol, this can modify the activity of antibiotics and therefore be used as adjuncts to antibiotic therapy against these pathogens. Thus, the search for natural compounds with antimicrobial activity and behavior is necessary for synergistic emergency control and treatment of diseases.

\section{References}

[1] C. S. Alaribe, F. Shode, A. B. Herbert et al., "Antimicrobial activities of hexane extract and decussatin from stembark extract of ficus congensis," International Journal of Molecular Sciences, vol. 12, pp. 2750-2756, 2011.

[2] F. Bakkali, S. Averbeck, D. Averbeck, and M. Idaomar, "Biological effects of essential oils-a review," Food and Chemical Toxicology, vol. 46, no. 2, pp. 446-475, 2008.

[3] A. Ait-Ouazzou, L. Cherrat, L. Espina, S. Lorán, C. Rota, and R. Pagán, "The antimicrobial activity of hydrophobic essential oil constituents acting alone or in combined processes of food preservation," Innovative Food Science and Emerging Technologies, vol. 12, no. 3, pp. 320-329, 2011.

[4] S. Burt, "Essential oils: their antibacterial properties and potential applications in foods-a review," International Journal of Food Microbiology, vol. 94, no. 3, pp. 223-253, 2004.

[5] F. F. G. Rodrigues, J. G. M. Costa, and H. D. M. Coutinho, "Synergy effects of the antibiotics gentamicin and the essential oil of Croton zehntneri," Phytomedicine, vol. 16, no. 11, pp. 1052$1055,2009$. 
[6] G. Gunics, S. Farkas, N. Motohashi et al., "Interaction between 3,5-diacetyl-1,4-dihydropyridines and ampicillin, and erythromycin on different E. coli strains," International Journal of Antimicrobial Agents, vol. 20, no. 3, pp. 227-229, 2002.

[7] K. Wolfart, G. Spengler, M. Kawase, N. Motohashi, J. Molnar, and M. Viveiros, "Interaction between 3,5-diacetyl-1,4dihydropyridines and ampicillin, and erythromycin on different E. coli strains," In Vivo, vol. 20, pp. 367-372, 2006.

[8] N. K. A. Santos, H. D. M. Coutinho, G. S. B. Viana, F. F. G. Rodrigues, and J. G. M. Costa, "Chemical characterization and synergistic antibiotic activity of volatile compounds from the essential oil of Vanillosmopsis arborea," Medicinal Chemistry Research, vol. 20, pp. 637-641, 2011.

[9] J. E. Dellar, M. D. Cole, and P. G. Waterman, "Antimicrobial abietane diterpenoids from Plectranthus elegans," Phytochemistry, vol. 41, no. 3, pp. 735-738, 1996.

[10] C. W. Lukhoba, M. S. J. Simmonds, and A. J. Paton, "Plectranthus: a review of ethnobotanical uses," Journal of Ethnopharmacology, vol. 103, no. 1, pp. 1-24, 2006.

[11] C. Gaspar-Marques, P. Rijo, M. F. Simões, M. A. Duarte, and B. Rodriguez, "Abietanes from Plectranthus grandidentatus and $P$. hereroensis against methicillin- and vancomycin-resistant bacteria," Phytomedicine, vol. 13, no. 4, pp. 267-271, 2006.

[12] F. J. A. Matos, Plantas Medicinais: Guia de Seleção e Emprego de Plantas Usadas em Fitoterapia no Nordeste do Brasil, IU, Fortaleza, Brazil, 2nd edition, 2000.

[13] R. A. D. G. De Oliveira, E. D. O. Lima, E. L. De Souza et al., "Interference of Plectranthus amboinicus (Lour.) Spreng essential oil on the anti-Candida activity of some clinically used antifungals," Brazilian Journal of Pharmacognosy, vol. 17, no. 2, pp. 186-190, 2007.

[14] J. G. M. da Costa, C. K. B. Pereira, F. F. G. Rodrigues, and S. G. de Lima, "Chemical composition, antibacterial and fungicidal activities of leaf oil of Plectranthus amboinicus (Lour.) Spreng," Journal of Essential Oil Research, vol. 22, no. 2, pp. 183-185, 2010.

[15] P. S. Murthy, K. Ramalakshmi, and P. Srinivas, "Fungitoxic activity of Indian borage (Plectranthus amboinicus) volatiles," Food Chemistry, vol. 114, no. 3, pp. 1014-1018, 2009.

[16] M. A. Jose and S. J. Ibrahim, "Modulatory effect of Plectranthus amboinicus Lour. on ethylene glycol-induced nephrolithiasis in rats," Indian Journal of Pharmacology, vol. 37, no. 1, pp. 43-44, 2005.

[17] P. M. Oliveira, A. A. Ferreira, D. Silveira et al., "Diterpenoids from the aerial parts of Plectranthus ornatus," Journal of Natural Products, vol. 68, no. 4, pp. 588-591, 2005.

[18] R. L. de Albuquerque, M. G. D. V. Silva, M. I. L. Machado, F. J. D. A. Matos, S. M. de Morais, and J. S. Neto, "Chemical composition and antioxidant activity of Plectranthus grandis and $P$. ornatus essential oils from north-eastern Brazil," Flavour and Fragrance Journal, vol. 22, no. 1, pp. 24-26, 2007.

[19] R. L. de Albuquerque, M.R. Kentopff, M. I. L. Machado et al., "Diterpeno tipo abietano isolados de Plectranthus barbatus ANDREWS," Química Nova, vol. 30, no. 8, pp. 1882-1886, 2007.

[20] P. Rijo, C. Gaspar-Marques, M. F. Simões et al., "Neoclerodane and labdane diterpenoids from Plectranthus ornatus," Journal of Natural Products, vol. 65, no. 10, pp. 1387-1390, 2002.

[21] NCCLS, "Methods for dilution antimicrobial susceptibility tests for bacteria that grow aerobically," NCCLS Document M7-A6, National Committee for Clinical Laboratory Standard, Wayne, Pa, USA, 2003.
[22] M. R. Kerntopf, R. L. De Albuquerque, M. I. L. Machado, F. J. A. Matos, and A. A. Craveiro, "Essential oils from leaves, stems and roots of Plectranthus barbatus Andr. (Labiatae) grown in Brazil," Journal of Essential Oil Research, vol. 14, no. 2, pp. 101-102, 2002.

[23] M. C. C. D. Costa, "Uso popular e ações farmacológicas de Plectranthus barbatus Andr. (Lamiaceae): revisão dos trabalhos publicados de 1970 a 2003," Revista Brasileira de Plantas Medicinais, vol. 8, no. 2, pp. 81-88, 2006.

[24] A. Senthilkumar and V. Venkatesalu, "Chemical composition and larvicidal activity of the essential oil of Plectranthus amboinicus (Lour.) Spreng against Anopheles stephensi: a malarial vector mosquito," Parasitology Research, vol. 107, no. 5, pp. 1275-1278, 2010.

[25] J. C. R. Nogueira, M. F. M. Diniz, and E. O. Lima, "Atividade antimicrobiana in vitro de produtos vegetais em otite externa aguda," Revista Brasileira de Otorrinolaringologia, vol. 74, no. 1, pp. 118-124, 2008.

[26] E. F. F. Matias, K. K. A. Santos, T. S. Almeida, J. G. M. Costa, and H. D. M. Coutinho, "Phytochemical prospection and modulation of aminoglycoside antibiotic activity by Croton campestris A.," Chemotherapy, vol. 57, no. 4, pp. 305-309, 2011.

[27] T. Rabe and J. Van Staden, "Screening of Plectranthus species for antibacterial activity," South African Journal of Botany, vol. 64, no. 1, pp. 62-65, 1998.

[28] C. F. Bagamboula, M. Uyttendaele, and J. Debevere, "Inhibitory effect of thyme and basil essential oils, carvacrol, thymol, estragol, linalool and p-cymene towards Shigella sonnei and S. flexneri," Food Microbiology, vol. 21, no. 1, pp. 33-42, 2004.

[29] H. D. Skaltsa, C. Demetzos, D. Lazari, and M. Sokovic, "Essential oil analysis and antimicrobial activity of eight Stachys species from Greece," Phytochemistry, vol. 64, no. 3, pp. 743-752, 2003.

[30] M. Skočibušić, N. Bezić, and V. Dunkić, "Phytochemical composition and antimicrobial activities of the essential oils from Satureja subspicata Vis. growing in Croatia," Food Chemistry, vol. 96, no. 1, pp. 20-28, 2006.

[31] T. M. A. Alves, A. F. Silva, M. Brandão et al., "Biological screening of Brazilian medicinal plants," Memórias do Instituto Oswaldo Cruz, vol. 95, no. 3, pp. 367-373, 2000.

[32] R. J. W. Lambert, P. N. Skandamis, P. J. Coote, and G. J. E. Nychas, "A study of the minimum inhibitory concentration and mode of action of oregano essential oil, thymol and carvacrol," Journal of Applied Microbiology, vol. 91, no. 3, pp. 453-462, 2001.

[33] E. L. Souza, T. L. M. Stamford, E. O. Lima, and V. N. Trajano, "Effectiveness of Origanum vulgare L. essential oil to inhibit the growth of food spoiling yeasts," Food Control, vol. 18, no. 5, pp. 409-413, 2007.

[34] S. Cosentino, C. I. G. Tuberoso, B. Pisano et al., "In-vitro antimicrobial activity and chemical composition of Sardinian Thymus essential oils," Letters in Applied Microbiology, vol. 29, no. 2, pp. 130-135, 1999.

[35] H. J. D. Dorman and S. G. Deans, "Antimicrobial agents from plants: antibacterial activity of plant volatile oils," Journal of Applied Microbiology, vol. 88, no. 2, pp. 308-316, 2000.

[36] D. Trombetta, F. Castelli, M. G. Sarpietro et al., "Mechanisms of antibacterial action of three monoterpenes," Antimicrobial Agents and Chemotherapy, vol. 49, no. 6, pp. 2474-2478, 2005.

[37] L. Ascensão, A. C. Figueiredo, J. G. Barroso et al., "Plectranthus madagascariensis: morphology of the glandular trichomes, essential oil composition, and its biological activity," International Journal of Plant Sciences, vol. 159, no. 1, pp. 31-38, 1998. 
[38] E. N. Matu and J. Van Staden, "Antibacterial and antiinflamatory activities of some plants used for medicinal purposes in Kenya," Journal of Ethnopharmacology, vol. 87, no. 1, pp. 35-41, 2003.

[39] N. A. Mat-Isa, M. Y. Mashor, and N. H. Othman, "Seeded region growing features extraction algorithm; its potential use in improving screening for cervical cancer," International Journal of the Computer, the Internet and Management, vol. 13, pp. 61-70, 2005.

[40] K. Nicolson, G. Evans, and P. W. Toole, "Potentiation of methicillin activity against methicillin-resistant Staphylococcus aureus by diterpenes," FEMS Microbiology Letters, vol. 179, pp. 233-239, 1999.

[41] H. D. M. Coutinho, F. F. G. Rodrigues, E. M. M. Nascimento, J. G. M. Costa, V. S. Falcão-Silva, and J. P. Siqueira-Júnior, "Synergism of gentamicin and norfloxacin with the volatile compounds of Lippia microphylla Cham. (Verbenaceae)," Journal of Essential Oil Research, vol. 23, no. 2, pp. 24-28, 2011.

[42] Z. Jedlickova, O. Mottl, and V. Sery, "Antibacterial properties of the Vietnamese Cajeput oil and Ocimum oil in combination with antibacterial agents," Journal of Hygiene Epidemiology Microbiology \& Immunology, vol. 36, no. 3, pp. 303-309, 1992.

[43] I. M. Helander, H. L. Alakomi, K. Latva-Kala et al., "Characterization of the action of selected essential oil components on gram-negative bacteria," Journal of Agricultural and Food Chemistry, vol. 46, no. 9, pp. 3590-3595, 1998.

[44] C. N. Wendakoon and S. Morihiko, "Inhibition of amino acid decarboxylase activity of enterobacter aerogenes by active components in spices," Journal of Food Protection, vol. 58, no. 3, pp. 280-283, 1995.

[45] T. P. Lim, T. Y. Tan, W. Lee et al., "In vitro activity of various combinations of antimicrobials against carbapenem-resistant Acinetobacter species in Singapore," Journal of Antibiotics, vol. 62, no. 12, pp. 675-679, 2009. 


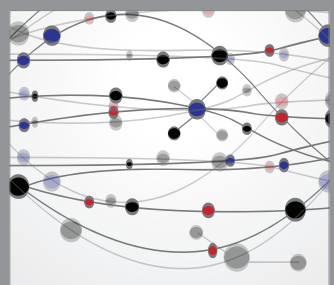

The Scientific World Journal
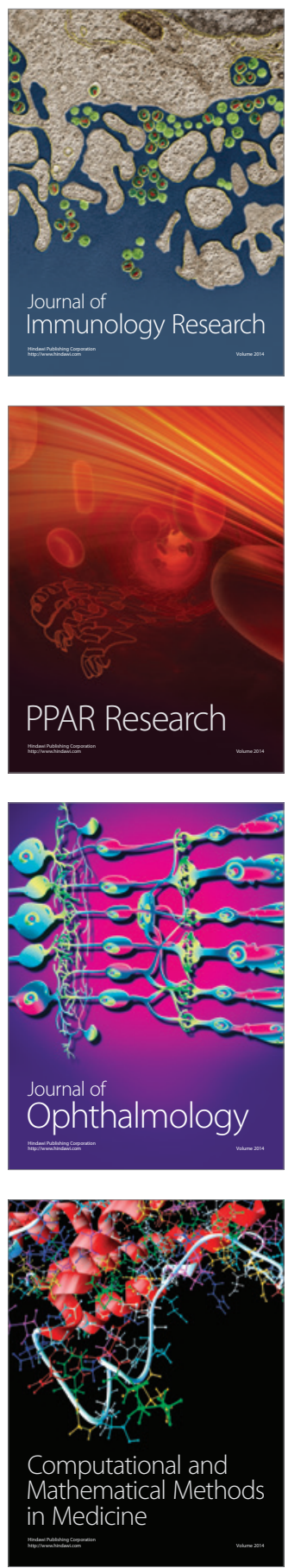

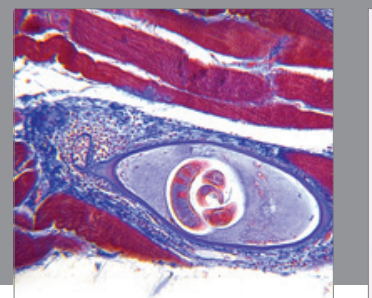

Gastroenterology

Research and Practice
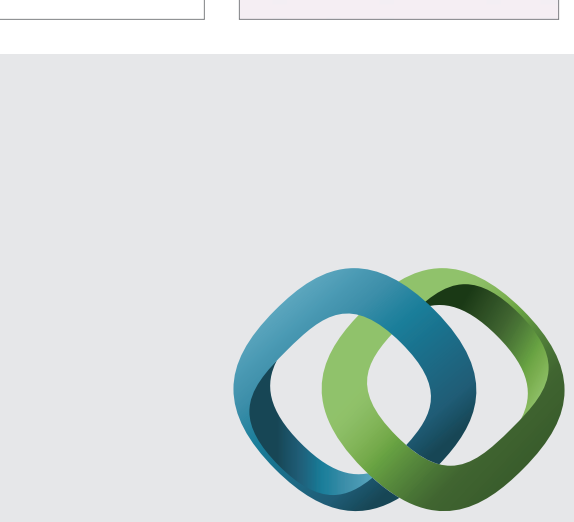

\section{Hindawi}

Submit your manuscripts at

http://www.hindawi.com
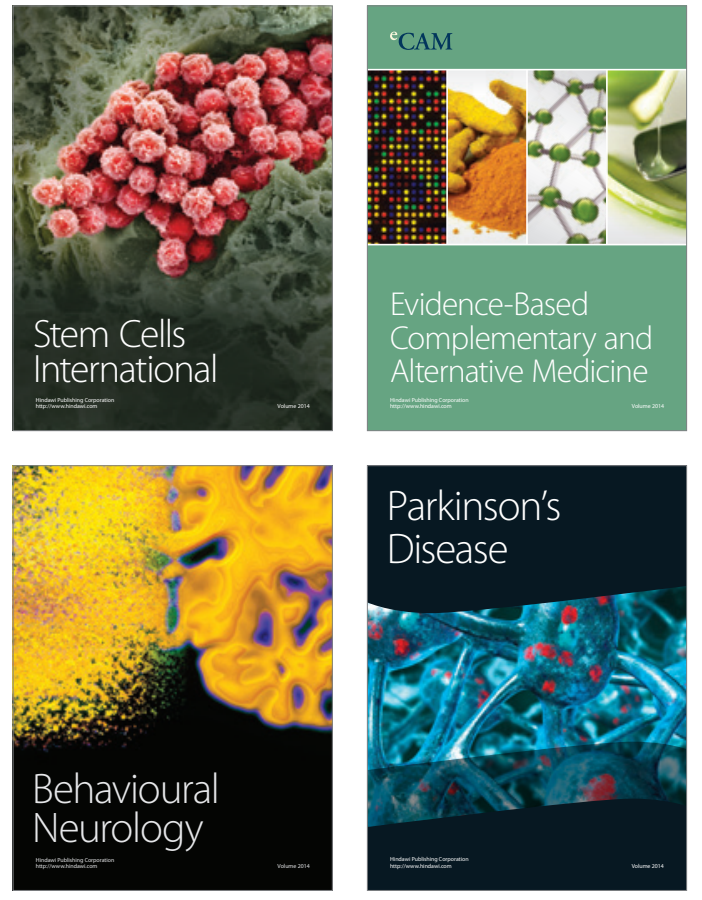
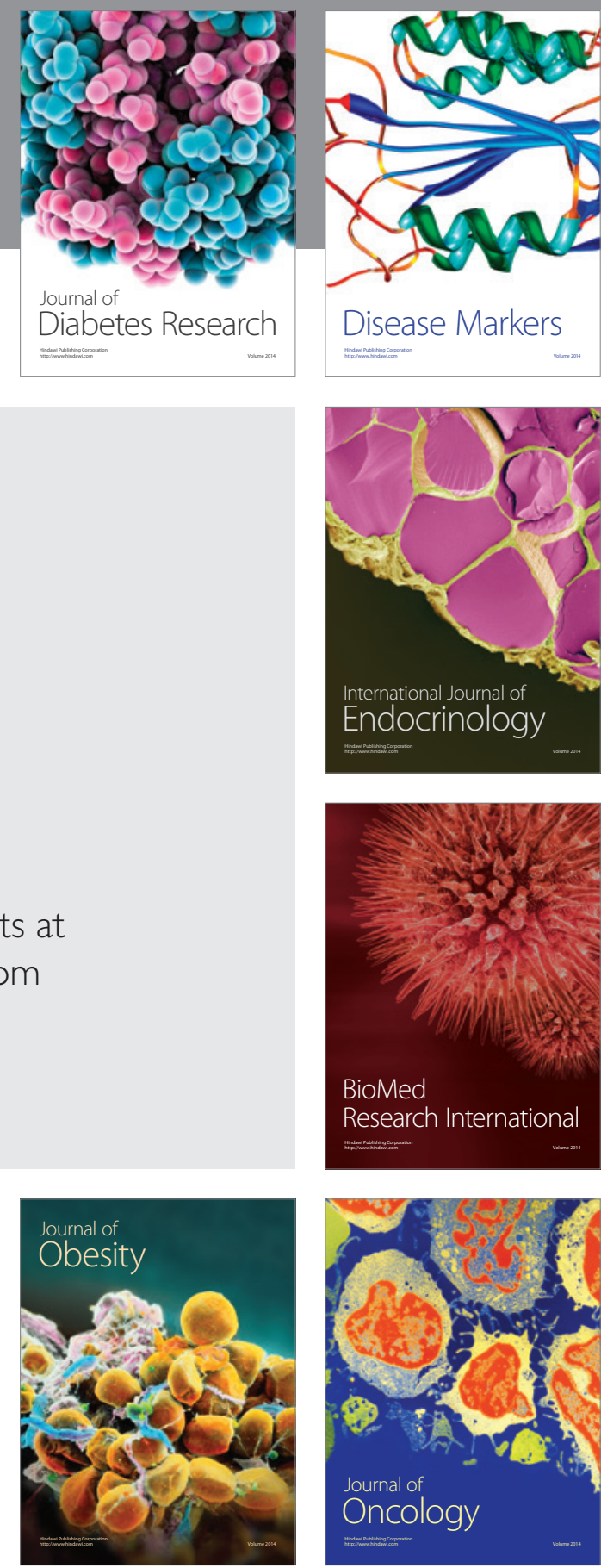

Disease Markers
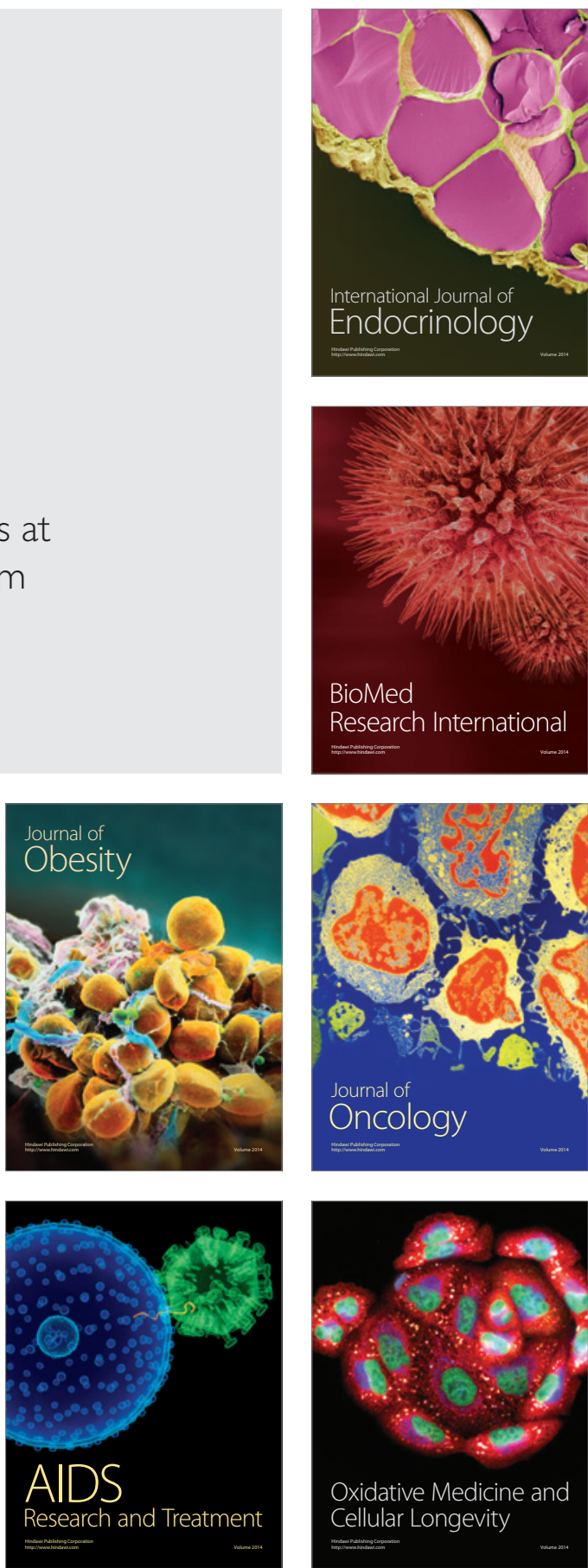